\title{
The Protoevangelium of James and Its Reception in the Caucasus: Status Quaestionis
}

\author{
Cornelia Horn
}

Martin-Luther University Halle-Wittenberg, Halle (Saale), Germany

cbhorn68@gmail.com,cornelia.horn@orientphil.uni-halle.de

\begin{abstract}
This article examines the status quaestionis concerning the Protoevangelium of James in the Caucasus, focusing on evidence in Armenian and Georgian sources.
\end{abstract}

\section{Keywords}

Protoevangelium ofJames - Armenian - Georgian - apocrypha - manuscripts

\section{Introduction and Background}

The Protoevangelium of James is a text, to which scholars at times also refer as the Infancy Gospel of James. ${ }^{1}$ Its origins go back as far as the second century $\mathrm{CE}^{2}{ }^{2}$ Being a narrative about the earlier stages of the life of Jesus' mother Mary and about Jesus' birth, this apocryphal infancy gospel is closely associated with

1 The research and writing of this article occurred in part while I held a Heisenberg Fellowship (GZ HO 5221/1-1) and in part during my tenure as Heisenberg Professor of Languages and Cultures of the Christian Orient at the Martin-Luther-University, Halle-Wittenberg (GZ HO 5221/2-1). I wish to express my gratitude to the Deutsche Forschungsgemeinschaft (DFG) for their financial support.

2 See S. Pellegrini, "Das Protevangelium des Jakobus," in: Antike christliche Apokryphen in deutscher Übersetzung. I. Band: Evangelien und Verwandtes, Teilband 2, eds. Chr. Markschies and J. Schröter, with A. Heiser, 7. Auflage der von Edgar Hennecke begründeten und von Wilhelm Schneemelcher fortgeführten Sammlung der neutestamentlichen Apokryphen, Tübingen, 2012, pp. 903-929, here p. 907; L.C. Vuong, Gender and Purity in the Protevangelium of James (Wissenschaftliche Untersuchungen zum Neuen Testament, 2.358), Tübingen, 2013, pp. 32-39 and 238-239. 
the world of images and events known from the Biblical stories. First and foremost it was concerned with the narratives that are included in the initial chapters of the New Testament gospels, which it retold or rewrote and supplemented as deemed necessary, helpful, or advisable. ${ }^{3}$ Yet the Protoevangelium of James was not a text that had come to be accepted formally as part of the biblical canon. ${ }^{4}$ In fact, especially in the West, it was referred to explicitly as an apocryphal gospel and was excluded from the canon. The Western position depended on the text's condemnation in the so-called Decretum Gelasianum, a work of late-fifth- or sixth-century Italy or Gaul. Characterizing a long list of writings as texts that were considered as having "been compiled or been

3 See Matt 1-2 and Luke 1-2. For the definition of the character of apocrypha, see É. Junod, "Apocryphes du Nouveau Testament," Apocrypha, 3 (1992), pp. 17-46; Chr. Markschies, “'Neutestamentliche Apokryphen': Bemerkungen zu Geschichte und Zukunft einer von Edgar Hennecke im Jahre 1904 begründeten Quellensammlung," Apocrypha, 9 (1998), pp. 97-132; S.C. Mimouni, "Le concept d'apocryphité dans le christianisme ancien et médiéval. Réflexions en guise d'introduction," in: Apocryphité. Histoire d'un concept transversal aux religions du livre. En hommage à Pierre Geoltrain, ed. S.C. Mimouni (Bibliothèque de l'École des Hautes Études. Section des Sciences religieuses, 113), Turnhout, 2002, pp. 1-30; T. Nicklas, "SemiotikIntertextualität-Apokryphität: Eine Annäherung an den Begriff 'christlicher Apokryhphen', Apocrypha, 17 (2006), pp. 55-77; P. Piovanelli, "Qu'est-ce qu'un 'écrit apocryphe chrétien', et comment ça marche? Quelques suggestions pour une herméneutique apocryphe," in: Pierre Geoltrain ou comment "faire l'histoire » des religions? Le chantier des « origines », les méthodes du doute et la conversation contemporaine entre les disciplines, ed. S.C. Mimouni and Isabelle Ullern-Weité (Histoire et prosopographie de la section des sciences religieuses, 2), Turnhout, 2006, pp. 173-186; T. Nicklas, "Écrites apocryphes chrétiens: ein Sammelband als Spiegel eines weitreichenden Paradigmenwechsels in der Apokryphenforschung," Vigiliae Christianae, 61 (2007), pp. 70-95; and C. Horn, "Christian Apocrypha in Georgia and in Literature on Georgians: Some Reflections on the Intersections of Apocrypha, Hagiography, and Liturgy," in: Proceedings of the Conference "Renaissance Humanism" in Honor of the 125th Anniversary of Shalva Nutsubidze, Institute of Philosophy, Ivane Javakhishvili Tbilisi State University, Tbilisi,

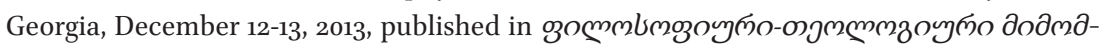

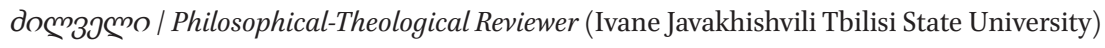
3 (2013), pp. 186-193. For a recent examination of the Protoevangelium of James as a text that relates to the New Testament gospels in a way that is similar to that of texts in the tradition of the rewritten Bible, see D.L. Smith, "Questions and Answers in the Protevangelium of James and the Gospel of Peter," in: Sacra Scriptura: How "Non-Canonical" Texts Functioned in Early Judaism and Early Christianity, eds. J.H. Charlesworth and L.M. McDonald with B.A. Jurgens, London - New Delhi - New York - Sidney, 2014, pp. 171-185, here pp. 172-174.

4 The question of the relationship of apocryphal writings to the Biblical canon may gain further clarification when we consider how apocryphal texts were at times simply treated as belonging to Scripture. See J. Henry, "The Acts of Thomas as Sacred Text," in: Sacra Scriptura, eds. Charlesworth and McDonald with Jurgens, pp. 153-170, here pp. 172-174. 
recognized by heretics or schismatics," the Decretum Gelasianum commented that the books in this list of apocryphal writings "the Catholic and Apostolic Roman Church does not in any way accept." Included in this list one finds "the Book on the Infancy of the Savior (Liber de infantia salvatoris)" and "the Book of the Nativity of the Savior and of Mary or the Midwife (Liber de nativitate salvatoris et de Maria vel obstetrice)," that is, the Infancy Gospel of PseudoThomas and the Protoevangelium of James, respectively. ${ }^{6}$ Whereas the first one remained outside the canon in both the West and the East, the infancy gospel under the name of James the Younger, which was judged to be "apocryphal" in the West, enjoyed an exceptionally wide and intensive reception in the Christian East. There, in fact, one might say that the Protoevangelium of James enjoyed a hybrid status which one could describe as being both apocryphal and quasi-canonical at the same time.

In the Christian East, the Protoevangelium of James has been used as a source of inspiration for the development of several important liturgical feasts of the Christian calendar. The Feast of Anna's Conception of Mary (December 9 in the East, December 8 in the West), the Feast of the Birth of Mary (September 8), the Feast of the Entry of the Mother of God into the Temple (November 21), also known, in the West, as the Feast of the Presentation of Mary in the Temple, and the Feast of Joachim and Anna, Mary's Parents (July 25 in the East, July 26 in the West) all have their roots in the account of Mary's childhood experiences that are featured in this apocryphal infancy gospel. ${ }^{7}$ This narrative, moreover, is the source text for well-known artistic and literary traditions about specific story elements that flesh out for the faithful the events of salvation history. The most widely known detail which found its place in the liturgical poetry and visual art of the East is Jesus' birth in a cave. The permanence and practically universal reception of this idea in the Christian East is documented in numerous icons of the Nativity in the Byzantine, Greek, and Russian traditions. ${ }^{8}$ For the minds and imaginations of the faithful in the East, the per-

E. von Dobschütz, Das Decretum Gelasianum de libris recipiendis et non recipiendis (Texte und Untersuchungen zur Geschichte der altchristlichen Literatur, 38.4), Leipzig, 1912, pp. 11 and 48 .

6 Von Dobschütz, Das Decretum Gelasianum, pp. 11 and 51; see also Chr. Markschies, "Haupteinleitung," in: Antike christliche Apokryphen in deutscher Übersetzung, I. Band, eds. Markschies and Schröter, with Heiser, pp. 1-180, here p. 137 with notes 459 and 460.

7 See for example J. Ledit, Marie dans la liturgie de Byzance (Théologie historique, 39), Paris, 1976, pp. 102-103, 109, 113, 118-119, 121, and 129.

8 See for instance R. Stichel, Die Geburt Christi in der russischen Ikonenmalerei: Voraussetzungen in Glauben und Kunst des christlichen Ostens und Westens, Stuttgart, 1990, plates $1-53,55^{-58}, 60-61,67,69,71,75^{-77}, 79$, and 86 . For a rich discussion of the liturgical and 
ception of the canonical narrative of the feasts that have been mentioned and the content that shaped the religious devotion was formed and nurtured by the details which the Protoevangelium of James offered. Other characteristic elements of this narrative include Mary spinning yarn inside or outside of a building or temple, and her holding a pitcher with water from a well in the annunciation story. These too appear in decorations of religious artefacts and large-scale objects of art from Late Antiquity. ${ }^{9}$

Thus far, scholars have turned their attention primarily to the study of the Greek original of the Protoevangelium of James. In 1961, the Jesuit Émile de Strycker published a critical edition of the Greek text, taking into account the important third-century evidence of Papyrus Bodmer 5, which Michel Testuz had published earlier on in $1958 .{ }^{10}$ Indeed, there continues to be a strong scholarly consensus that the story originated in Greek in the second century. Based on manuscript witnesses, consisting of Greek papyri as well as manuscript fragments of Coptic (Sahidic) and Syriac versions, the first phase of textual development of the Protoevangelium of James is to be located between the third century and the middle of the fifth century.11

The second phase of the textual development extends from the fifth century to about 9oo. This phase, as de Strycker has shown, is supported by the evidence of the Georgian, the Armenian, and the Latin versions, alongside further Greek papyri and the reworking of the text in Latin, for instance in the Gospel of Pseudo-Matthew. ${ }^{12}$ The bulk of the Greek evidence is available in manuscripts dating from 900 onwards; at least 117 witnesses testify to the wide diffusion of the Protoevangelium of James in the liturgy and in the ascetic milieu of

mystagogical dimensions of the image of the cave, see K. Onasch, Das Weihnachtsfest im orthodoxen Kirchenjahr. Liturgie und Ikonographie (Quellen und Untersuchungen zur Konfessionskunde der Orthodoxie, 2), Berlin, 1958, pp. 175-194.

See for instance the mosaic of the Annunciation on the Triumphal Arch at Santa Maria Maggiore in Rome. See J. Wilpert und W.N. Schumacher, Die römischen Mosaiken der kirchlichen Bauten vom IV.-XIII. Jahrhundert, Freiburg - Basel - Vienna, 1976, plates 51-53 and p. 316 (description offered by J.G. Deckers).

É. de Strycker, La forme la plus ancienne du Protévangile de Jacques. Recherches sur le Papyrus Bodmer 5 avec une édition critique du texte grec et une traduction annotée, with the appendix Les versions arméniennes traduites en Latin by H. Quecke (Subsidia Hagiographica, 33), Bruxelles, 1961; M. Testuz, Nativité de Marie (Papyrus Bodmer, 5), Cologne Geneva, 1958. ancienne du Protévangile de Jacques, pp. 35-39 and 43-47. 
the Christian East. The Georgian and Armenian evidence, however, has not received sufficient systematic attention thus far.

More recently, characteristic aspects of the text have come into focus that can be lifted at times from the Syriac versions of the Protoevangelium of James and that increase our insights for instance into women's history, childhood history, Jewish-Christian relations, or the impact of Christian apocrypha on Islamic origins. ${ }^{13}$ Yet for the most part, neither the text-critical, nor the socialcritical and cultural-critical value of the evidence of the complete range of the Christian Oriental versions of the Protoevangelium of James have been explored. Indeed, with the exception of the Greek tradition, none of the Christian Oriental versions of the text are available or accessible in a proper critical edition. ${ }^{14}$ Recent developments in the realm of the Digital Humanities prompt one to expect that much could be gained if one were to produce a digital edition of the Protoevangelium of James, especially if such an edition would be able to integrate not only all Christian Oriental traditions, but also the Slavonic witnesses. One of the steps on the way towards this goal is a critical digital edition of the Armenian and of the Georgian evidence of the Protoevangelium of James. This article contributes towards this goal by reexamining the source material from the Caucasus that de Strycker had available. At the same time, this article provides an update of new discoveries pertinent to the Armenian and Georgian versions and their reception.

13 See for instance Vuong, Gender and Purity; M.F. Foskett, "The Child Mary in the Protevangelium of James," in: "Non-Canonical" Religious Texts in Early Judaism and Early Christianity, eds. L.M. McDonald and J.H. Charlesworth, New York, 2012, pp. 195-204; T. Horner, "Jewish Aspects of the Protevangelium of James," Journal of Early Christian Studies, 12 (2004), pp. 313-335; L. Vuong, "Let Us Bring Her Up to the Temple of the Lord.' Exploring the Boundaries of Jewish and Christian Relations through the Presentation of Mary in the Protevangelium of James," in: Infancy Gospels. Stories and Identities, eds. C. Clivaz, A. Dettwiler, L. Devillers, and E. Norelli, with the assistance of B. Bertho (Wissenschaftliche Untersuchungen zum Neuen Testament, 281), Tübingen, 2011, pp. 418-432; C. Horn, "Syriac and Arabic Perspectives on Structural and Motif Parallels Regarding Jesus' Childhood in Christian Apocrypha and Early Islamic Literature: the 'Book of Mary,' the Arabic Apocryphal Gospel of John, and the Qur'ān," Apocrypha. Revue internationale des littératures apocryphes, 19 (2008), pp. 267-291.

14 It is to be expected that the volume on the Protoevangelium of James, which is under preparation by the relevant subject team of members of the Association pour l'Études de la Littérature Apocryphe Chrétienne (AELAC) under the guidance of Albert Frey will improve this situation. See for now A. Frey, introduction and translation, "Protévangile de Jacques," in Écrits apocryphes chrétiens, vol. 1, eds. P. Geoltrain and F. Bovon (Bibliothèque de la Pléiade, 442), Paris, 1997, pp. 73-104. 


\section{The Armenian Evidence for the Protoevangelium of James}

The evidence for the Armenian version of the Protoevangelium of James comprises four manuscripts, dating from the ninth to the fifteenth century, that have been identified and worked with thus far. The Mekhitarist Father Isaiah Tayets'i published three of these witnesses in 1898 , whereas the fourth manuscript witness has only been identified more recently. ${ }^{15}$ Armenian Ms. 203 (formerly 985) of the Library of San Lazzaro in Venice, which dates to the thirteenth or fourteenth century, offers an almost complete text of the Armenian version. ${ }^{16}$ Only the last chapter, number 25 , is absent from this witness. A full version is contained in San Lazzaro Ms. 223 (formerly 1447), which dates to the fifteenth century. ${ }^{17}$ The oldest of the three manuscripts which Tayets'i published is San Lazzaro Armenian Ms. 201 (formerly 1014), dated to the period from the twelfth to the thirteenth century. ${ }^{18}$ Yet this third manuscript witness is fragmentary, preserving only the text of the first six chapters.

In 1961, the Jesuit scholar Hans Quecke published Latin translations of these three Armenian witnesses based on Tayets'i's edition and photographs of the manuscripts. Quecke's translations appeared as an appendix to de Strycker's edition and study of the Greek text of the Protoevangelium of James. ${ }^{19}$ Most recently, Abraham Terian published English translations of these three witnesses to the Armenian version. His translations appeared as appendix one to his English translation of the Armenian Infancy Gospel in 2008. ${ }^{20}$ Based on Quecke's Latin translations, de Strycker analyzed and carefully compared the texts of the three Armenian witnesses. He noted considerable differences

15 Isaiah Tayets'i, Uiquukni qhpp Unp Yunulumpuing [Non-canonical Books of the

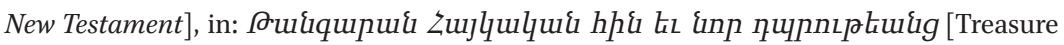
of Armenian Literature, Ancient and Modern], Venice, 1898, vol. II, pp. 237-267. The text of Ms. 203 is on pp. 237-250, that of Ms. 223 is on pp. 250-264, and that of Ms. 201 is on pp. 264-267.

16 Barsegh Sargisean, Uujn gnhguly hujtenti dtnuqpung Uuintinumupuihis Uhppupkuing h Utiquinhl / Grand catalogue des manuscrits arméniens de la Bibliothèque des PP. Mékhitharistes de Saint-Lazare [Mayr ts'uts'ak hayerēn dzeragrats' Matenadaranin Mkhit'areants' $i$ Venetik; Great Catalogue of the Armenian Manuscripts of the Library of the Mekhitarist Fathers at St. Lazarus], Venice, 1914-1924, vol. 2, cols. 113-134. Sargisean, Uujn gnhgull hujtptif dtnuqpuig, vol. 2, cols. 351-384.

18 Ibid., cols. 35-66.

19 H. Quecke, "Les versions arméniennes traduites en Latin," in: de Strycker, La forme la plus ancienne du Protévangile de Jacques, pp. 441-473. 
between the two ample witnesses Ms. 203 and Ms. 223. Nevertheless, de Strycker concluded that both manuscripts were witnesses to one and the same version. ${ }^{21}$ The incomplete Ms. 201 represents an independent version. Thus, one might conclude that the Protoevangelium of James was translated at least twice into Armenian. ${ }^{22}$ Terian's English translation made these two versions of the Armenian Protoevanglium of James available to a wider audience, all the while leaving the manuscript basis for the text untouched.

Until relatively recently, Tayets'i's, Quecke's, and de Strycker's work reflected the status quaestionis on the Armenian version of the Protoevangelium of James. The discovery or at least identification of a fourth manuscript witness for the Armenian text changed that situation. This new identification was one of the many scholarly achievements of Michel van Esbroeck.

In 2003, Francesco D'Aiuto had called attention to Vatican Ms. Sir 623, a parchment codex, which is dated on the basis of colophons to $886 \mathrm{CE} .^{23}$ This manuscript features primarily hagiographical and ascetic texts. ${ }^{24}$ The second part of the manuscript (ff. 105-227) consists of a palimpsest, comprising numerous contributing manuscripts in the underlying layer. Of relevance for the present discussion are two bifolia pages (ff. 197, 204, 214, and 215), the underlying layer of which features text in Armenian erkat'agir, or majuscule, script. ${ }^{25}$ Given the presence of a colophon on the pages of the upper text, which is dated to $886 \mathrm{CE}$, the underlying Armenian text can safely be presumed to predate the late ninth century. D'Aiuto noted that this dating places the Armenian text

21 De Strycker, La forme la plus ancienne du Protévangile de Jacques, pp. 355-358.

22 See also ibid., pp. 358-359.

23 F. D'Aiuto, "Graeca in Codici Orientali della Biblioteca Vaticana (con i resti di un manoscritto tardoantico delle Commedie di Menandro)," in: Tra Oriente e Occidente. Scritture e libri greci fra le regioni orientali di Bisanzio e l'Italia, ed. L. Perria (Testi e Studi BizantinoNeoellenici, 14), Roma, 2003, pp. 227-296, here p. 266.

24 For a summary description of the manuscript, see A. Van Lantschoot, Inventaire des manuscrits syriaques des fonds Vatican (490 [sic!]-631). Barberini Oriental et Neofiti (Studi e testi, 243), Città del Vaticano, 1965, pp. 151-153. In fact, the volume presents texts starting with Ms. Vat. 46o. M. van Esbroeck, "Les versions orientales de la Bible: Une orientation bibliographique," in: Interpretation of the Bible. International Symposium on the Interpretation of the Bible on the Occasion of the Publication of the New Slovenian Translation of the Bible (17-2o September 1996), Ljubljana, Slovenia, ed. J. Krašovec (Jsots, 289), Sheffield, 1998, pp. 399-509, here pp. 500-501, commented on the transition of Vatican Ms. Syr. 623 from the hands of private collectors into that of a library. A. de Halleux, "Un chapitre retrouvé du Livre de la perfection de Martyrius," Le Muséon, 88 (1975), pp. 253-296, here p. 253, fn. 7, lists Vatican Ms. Syr. 623 as a witness for Martyrius' Book of Perfection.

D’Aiuto, “Graeca in Codici Orientali delle Biblioteca Vaticana,” p. 268. 
in the immediate vicinity of the Lazarean Gospels (Yerevan Ms Matenadaran 6200), which next to the Queen Mlk'ē Gospels (Venice, Mekhitarist Library of San Lazzaro, 1144/86, dated to 862 or $902 \mathrm{CE})^{26}$ is considered to be the oldest dated ancient manuscript in Armenian. ${ }^{27}$ This newly identified Armenian palimpsest fragment then constitutes one of the earliest dated Armenian manuscript witnesses that have been preserved. The detailed examination of the two Armenian palimpsest pages remains a task for further research. Relying on comments which Delio Vania Proverbio published in 2002 in the context of discussing the Arabic fragments of Theon of Alexandria, ${ }^{28}$ D'Aiuto noted that Michel van Esbroeck had identified the Armenian palimpsest text on folio $204 \mathrm{~V}$ of Vatican Ms. Syr. 623 as a part of the Armenian version of the Protoevangelium of James. ${ }^{29}$ One may note then that this evidence is earlier than any of the other manuscript witnesses for the Armenian Protoevangelium of James that had heretofore been discovered. Moreover, this evidence also establishes that the written, dated testimony for the Protoevangelium of James is at least of the same antiquity as is the written, dated manuscript evidence for the canonical gospels in the Armenian tradition.

In the Armenian tradition, the Protoevangelium of James was transmitted directly as a free-standing text. Yet it also was received in various other forms, including those of rewriting and incorporating the text into other literary narratives. In fact, this approach of transmitting and reworking infancy gospels in Armenian produced an entertaining and richly detailed narrative known as the Armenian Infancy Gospel. Tayets'i was the first to publish longer and shorter recensions of this infancy gospel in Venice, in 1898, on the basis of two manuscripts. ${ }^{30}$ In 1897, Frederick Cornwallis Conybeare had already published an

26 For representations of pages from the Queen Mlk'ē Gospels, see the depictions in M.E. Stone, D. Kouymjian, and H. Lehmann, Album of Armenian Paleography, Aarhus, 2002, pp. 119 and 121.

27 D'Aiuto, “Graeca in Codici Orientali delle Biblioteca Vaticana," p. 268.

28 D.V. Proverbio, "Theonis Alexandrini fragmentum pervetus Arabice. Sul più antico manoscritto del Commentarium parvum di Teone Alessandrino. Notizia preliminare," Atti della Accademia Nazionale dei Lincei. Classe di scienze morali, storiche e filologiche. Rendiconti IX s., 13 III (2002), pp. 373-386, here p. 374.

See also S.J. Voicu, "Ways to Survival for the Infancy Apocrypha," in: Infancy Gospels. Stories and Identities, eds. C. Clivaz, A. Dettwiler, L. Devillers, and E. Norelli, with the assistance of B. Bertho (Wissenschaftliche Untersuchungen zum Neuen Testament, 281), Tübingen, 2011, pp. 401-417, here p. 409, fn. 39.

Editions of the two recensions of the Armenian text of the Armenian Infancy Gospel are available in Tayets'i, Uklquing qhpp Unp Gunulumpuiuug, vol. 2, pp. 1-126 and 
English translation of a fragmentary text, which he thought was an Armenian witness to the Protoevangelium of James. ${ }^{31}$ Paul Peeters and, following him, de Strycker, however, identified the fragment that had attracted Conybeare's attention as the first six chapters of the Armenian Infancy Gospel. ${ }^{32}$

In essence, the Armenian Infancy Gospel is a composite apocryphal gospel. As such, it incorporated much of the story of the Protoevangelium of James. In earlier years, scholarly judgments on this reception process had been less than favorable. In 1961, for instance, de Strycker had disqualified the value of the Armenian Infancy Gospel's reworking of the material from the Protoevangelium of James. For him, the Armenian Infancy Gospel was a verbose paraphrase of the Protoevangelium of James, a derivative work marked by a large number of inversions, suppressions, and additions. ${ }^{33}$ Yet de Strycker's assessment presumed that the establishment of the Urtext of the Protoevangelium of James was more or less the sole or prime goal of the textual critic, a perspective that was the norm in philological and text-critical studies in his discipline during this epoch. Such an approach, however, fails to appreciate the value of the $\mathrm{Ar}$ menian Infancy Gospel as a witness to the interpretive and transformative processes in the course of which preceding texts were acculturated to contemporary contexts through editing, reediting, and rewriting.

A different approach may lead one to a better appreciation of the work of reception and acculturated transformation, which the Armenian Infancy Gospel achieved with regard to the Protoevangelium of James. Such an approach analyzes the Armenian Infancy Gospel in close comparison with the Protoevangelium of James, searching for differences and similarities, yet with a view toward capturing the transformations of the Protoevangelium of James in Armenian culture and ascertaining the new ideas and purposes to the support

127-235. P. Peeters, Évangiles apocryphes II: L'Évangile de l'enfance. Rédactions syriaques, arabe et arméniennes traduites et annotées (Textes et documents pour l'étude historique du christianisme, 18), Paris, 1914, pp. 69-286, provided a French translation. Most recently, Terian, Armenian Gospel of the Infancy, pp. 3-149, has offered a translation of one of the three recensions of the longer version into English. The main manuscript for this text is Matenadaran Ms M7574.

F.C. Conybeare, "Protevangelium Iacobi [From an Armenian Manuscript in the Library of the Mechitarists in Venice]," The American Journal of Theology, 1.2 (1897), pp. 424-442.

Peeters, Évangiles apocryphes II, p. xxix; and de Strycker, La forme la plus ancienne du Protévangile de Jacques, p. 44. Although Conybeare did not provide information concerning the manuscript basis for the Armenian text he translated, he seems to have ended up rendering the version Tayets'i had published from Ms Armenian San Lazzaro 201. See Conybeare, "Protevangelium Iacobi," p. 440.

De Strycker, La forme la plus ancienne du Protévangile de Jacques, p. 44. 
of which the selections from the Protoevangelium of James were edited. Recently, Valentina Calzolari and Igor Dorfmann-Lazarev, working independently of one another, have taken some first steps in that direction. ${ }^{34}$ Such a line of inquiry could be continued and extended in future studies with great promise. It will be necessary to study in detail the textual and literary relationships between the Protoevangelium of James and the Armenian Infancy Gospel, especially in its first sections, in order to determine more closely the transformations, intended or unintended, to which the material that derived from the Protoevangelium of James was subjected when it was taken up into the Armenian Infancy Gospel. At the same time, it will be necessary to analyze what new theological and ideological changes manifest themselves in that process, be that with regard to ideas about Jesus' divinity and humanity, Mary's place in relation to the community of the believers, ideas about the roles of women and men in society and their relationships to one another, or with regard to the interrelationships of cultural and religious factors.

\section{The Georgian Evidence for the Protoevangelium of James}

Until 1955, when Michael Tarchnishvili and Julius Assfalg published their history of Georgian literature, scholars had only taken note of two witnesses to the transmission and reception of the Protoevangelium of James in Georgian. ${ }^{35}$ The first direct witness which Tarchnishvili identified was Georgian Ms. Sinai

34 See I. Dorfmann-Lazarev, "The Cave of the Nativity Revisited: Memory of the Primæval Beings in the Armenian Lord's Infancy and Cognate Sources," in: Mélanges Jean-Pierre Mahé, eds. A. Mardirossian, A. Ouzounian, and C. Zuckerman (Travaux et Mémoires, 18), Paris, 2014, pp. 285-334; I. Dorfmann-Lazarev, "Rückkehr zur Geburtsgrotte. Eine Untersuchung des armenischen Berichts über die Kindheit des Herrn," Theologie der Gegenwart, 56.1 (2013), pp. 30-43; V. Calzolari, "Les récits apocryphes de l'enfance dans la tradition arménienne," in: Infancy Gospels. Stories and Identities, eds. Clivaz, Dettwiler, Devillers, and Norelli, pp.560-587; I. Dorfmann-Lazarev, "La transmission de l'apocryphe de l'Enfance de Jésus en Arménie," in: Jesus in apokryphen Evangelienüberlieferungen; Beiträge zur ausserkanonischen Jesusüberlieferungen aus verschiedenen Sprach- und Kulturtraditionen, eds. Jörg Frey and Jens Schröter (wUNT, 254), Tübingen, 2010, pp. 557-582.

M. Tarchnishvili and J. Assfalg, Geschichte der kirchlichen georgischen Literatur (Studi e Testi, 185), Città del Vaticano, 1955, p. 337. On Michael Tarchnishvili and his accomplishments, see T. Tchumbaridze, "Michael Tarchnischvili (1897-1958)," in: Christlicher Orient im Porträt-Wissenschaftsgeschichte des Christlichen Orients. Kongreßakten der 1. Tagung der RVO (4. Dezember 2010, Tübingen), Teilband 2 (Religionen im Vorderen Orient, 3), Hamburg, 2014, pp. 773-793. 
6. ${ }^{36}$ This manuscript was written by three scribes, one identified by name as the rather well-known copyist John Zosimus, and two anonymous scribes whom John Zosimus had commissioned to assist him, one of whom copied the section that contains the Protoevangelium of James. Based on data contained in several colophons, Zosimus' work on the manuscript is datable to $981-983$ CE.

In pursuit of the sketch of the status quaestionis of scholarship on the Protoevangelium of James in the Caucasus it is necessary to discuss the evidence in MS Sinai Georgian 6 a bit more closely. We are dealing here with a parchment manuscript of 225 folios, written in nuskhuri script without columns. The texts are primarily hagiographies of ascetics and martyrdom accounts, including those of several female saints. The collection also features letters and, as the final document, it offers a treatise on the Georgian language. The Georgian text of the Protoevangelium of James is presented as the first text of the collection, on folios $2 \mathrm{r}$ to $12 \mathrm{r}$.

In his edition of the evidence of Ms. Sinai 6 for the Protoevangelium of James, Gérard Garitte argued on the basis of this information in the colophons that the text was copied in this Sinai manuscript prior to $983 \mathrm{CE} .{ }^{37}$ Yet Garitte also convincingly argued that the emergence of a Georgian translation of the Protoevangelium of James predated the evidence of Georgian Ms Sinai 6 by at least a century. Indeed, one could argue in favor of such a chronological delineation of the appearance of a Georgian translation of the Protoevangelium of James on Sinai. Garitte pointed to the evidence offered in Ms Sinai Georgian 32-57-33, a manuscript that represents what Albert Ehrhard would have called a panegyric, that is, a collection of homilies by various fathers and theologians of the church and of apocryphal texts that address topics relevant to feast days of Jesus and Mary. Following Michel van Esbroeck's analysis, we have in Ms. Sinai Georgian 32-57-33 the oldest dated mravalt'avi manuscript in Georgian, which

36 According to another designation system, Tsagareli 71; see А.А. Цагарели, “Каталогъ грузинскихъ рукописей Синайскаго монастыря" [A.A. Tsagareli, "Catalogue of the Georgian manuscripts of the Sinai monastery"], in: А. Цагарели, Памятники грузинской старины в Свлтой Зетле и на Синап [A. Tsagareli, Monuments of Georgian Antiquity in the Holy Land and on Sinai] (Православный палестинский сборник, IV.1), St. Petersburg, 1888, appendix II, pp. 193-240, here p. 227.

37 G. Garitte, "Le 'Protévangile de Jacques' en géorgien," Le Muséon, 70 (1957), pp. 233-265, here pp. 233 and 239; and idem, Catalogue des manuscrits géorgiens littéraires du Mont Sinaï (Corpus Scriptorum Christianorum Orientalium, 165; Subsidia, 9), Louvain, 1956, pp. $15^{-26 .}$ 
was copied at Mar Saba in $864 \mathrm{CE} .{ }^{38}$ On folio 206ra, this manuscript features a rubric testifying to the liturgical usage of the Protoevangelium of James, presumably in the Georgian-speaking realm, as a reading for September 8, the feast of the nativity of the Mother of God. The note includes the comment that on that feast day "they shall read the book of her nativity (dobols dmöobse fozbo Gsozoobm6)." 39 This comment presumes, also for a Georgian-language context on Sinai during the second half of the ninth century, the existence of a Georgian version of the Protoevangelium of James and its liturgical use. Thus far, no other evidence challenges Garitte's observations regarding the appearance of the Georgian text of the Protoevangelium of James on Sinai in the course of the ninth century.

Ilia Abuladze reprinted the first edition of the Georgian Protoevangelium of James in 1947, based on a published copy, which Ivan J̌avakhišvili had written out on Sinai and then printed as an appendix to a catalogue in $1902 .{ }^{40}$ Javakhišvili's edition offered merely the Georgian text as copied from the manuscript, with neither critical changes, resolutions of abbreviations, translation, nor commentary. Ten years later, in 1957, Gérard Garitte published a critical edition of the same text in Le Muséon. ${ }^{41}$ Although he noted individual erroneous readings of the Georgian text which might go back to a misreading of a Greek original, the number of such cases was rather small. Garitte observed a larger number of variants, where the Georgian formulations differed significantly from the Greek text of the Protoevangelium of James in a way that suggested an intermediary in between the Greek original and the Georgian translation. Parallels between the Georgian idiosyncrasies of the text and the Syriac version of the Protoevangelium of James do not seem to exist. Thus, an Armenian translation remains as the most likely candidate for the role of the intermediary. Already in 1903, Nikolai Marr had suggested that the Georgian text was translated from an Armenian version of the Protoevangelium of James. ${ }^{42}$ Yet neither of the known Armenian witnesses can be the Vorlage of

38 M. van Esbroeck, Les plus anciens homéliaires géorgiens. Études descriptive et historique (Publications de l'Institut Orientaliste de Louvain, 10), Louvain-la-Neuve, 1975, pp. 28-29; Garitte, "Le 'Protévangile de Jacques' en géorgien," p. 239; Garitte, Catalogue, p. 72.

39 Garitte, Catalogue, p. 87; Garitte, "Le 'Protévangile de Jacques' en géorgien," p. 241, fn. 19; Van Esbroeck, Les plus anciens homéliaires géorgiens, p. 129.

I.A. J̌avakhišvili, lobol dool fsஙonym by the Georgian Manuscripts on Mount Sinai] (Sak'art'velos ssR mec'nierebat'a Akademia. Sak'art'velos Saxelmcip‘o Muzeumi), Tiflis, 1947, pp. 184-193; Garitte, Catalogue, p. 15. Garitte, "Le 'Protévangile de Jacques' en géorgien."

42 Н. Марр, “Предварительный отчет о работах на Синае, веденных в сотрудничествие с И.А. Джаваховым, и в Иерусалиме, в поездку 1902 г. (апрель-ноябрь)” [N. Marr, 
the Georgian version. Nevertheless, Garitte was able to point out noteworthy correspondences between the Georgian and the Armenian text that make the existence of an Armenian translation as a Vorlage for the Georgian translation the most likely option. ${ }^{43}$

Michael Tarchnishvili noted that the text of the Protoevangelium of James in Ms. Sinai Georgian 6 is an integral part of a collection of Georgian texts, which were translated or edited by the famous Athonite monk and abbot, Euthymius Mt'ac'mindeli (ca 955/963-13th of May, 1028). ${ }^{44}$ Euthymius is thought to have taken up translating works into Georgian at the prompting of his father already at a young age during his teenage years, between the years 975 and 977, given that one set of his translations from Greek into Georgian, the text of the Apocalypse of John and Andrew of Caesarea's Commentary on the Apocalypse, had been copied by the scribe Sabas in $978 \mathrm{CE}$. In the Life of Euthymius of Mount Athos one can find a list of the translations into Georgian this famous monk is known to have produced. Among several other apocryphal works, this list also includes a text on the early years of the life of the Mother of God, perhaps being the Protoevangelium of James. ${ }^{45}$ It is possible, in principle, then that Ms. Sinai Georgian 6, in which the text of the Georgian Protoevangelium of James was copied prior to 983, could preserve a copy of Euthymius' translation. Indeed, if the Georgian Protoevangelium of James spread so quickly from one monastery to the next in regions inhabited by Georgians, one could take this observation as evidence for the relatively lively interest in this apocryphal composition on the early years of Mary's life and the birth of Jesus around the turn of the millennium among the populations of the Caucasus. Yet more de-

"Preliminary Report concerning the Works Conducted in Cooperation with I.A. Dzhavakhov, and in Jerusalem on a Trip in 1902 (April-November)"], in: Сообщения Императическаго Правнославнаго Палестинскаго Общества [Notes of the Imperial Orthodox Palestinian Society] XIV.2 (1903), pp. 1-51, here p. 20.

43 Garitte, "Le 'Protévangile de Jacques' en géorgien," pp. 235-239.

44 Tarchnishvili and Assfalg, Geschichte der kirchlichen georgischen Literatur, p. 128.

45 George the Hagiorite, Life of John and Euthymius 13 (trans. T. Grdzelidze, Georgian Monks on Mount Athos. Two Eleventh-Century Lives of the Hegoumenoi of Iviron, London, 2009, p. 69); Tarchnishvili and Assfalg, Geschichte der kirchlichen georgischen Literatur, pp. 133 and 337. Although the list of books in the Life of John and Euthymius refers merely to one text, On the Birth of the Holy Mother of God, Euthymius may have been involved in translating the Protoevangelium of James and the Life of the Virgin, ascribed to Maximus the Confessor. According to the text offered in N. Doborjginidze, Die georgische Sprache im Mittelalter (Sprachen und Kulturen des christlichen Orients, 17), Wiesbaden, 2009, pp. 128-129, Euthymius instead translated a homily of John of Damascus on the Birth of the Mother of God, which has not yet been identified any further. See Doborjginidze, Die georgische Sprache, pp. 210-211. 
tailed examination of the style of translation in Ms. Sinai Georgian 6 is necessary before it can be established that the Protoevangelium of James in this manuscript derives indeed from Euthymius.

The evidence of Ms. Sinai Georgian 32-57-33 suggests that Euthymius was not the only and not the first Georgian translator of the Protoevangelium of James into Georgian. Moreover, the existence of a separate recension of the Georgian text of the Protoevangelium of James among the manuscript witnesses in the collection of Mount Athos that has come to light may be taken as an indicator that Euthymius' translation may have been preserved on Athos, but perhaps not in the recension in Ms. Sinai Georgian 6.

Subsequent to J̌avakhišvili's and Garitte's studies, further progress towards identifying and editing the Georgian evidence of the Protoevangelium of James was published in 1970, with James Neville Birdsall's editio princeps of the witness in palimpsest Ms. Vindobonensis Georgicus 2. ${ }^{46}$ This manuscript is a valuable witness to early Georgian literature, with a number of biblical, hagiographical, and homiletic texts. The layer of the palimpsest that witnesses to the Protoevangelium of James can be dated to the fifth to eighth centuries.

James Birdsall had informed the public about the relevance of this manuscript evidence in the preceding year in his article in Oriens Christianus. ${ }^{47}$ Grigol Peradze appears to have been the first scholar ever to have drawn attention to the value of this manuscript as evidence for the Georgian Protoevangelium of James, publishing his conclusions in $1940 .{ }^{48}$ In 1977, Akaki Shanidze published the evidence for the Protoevangelium of James that is contained in the palimpsest layers of Ms. Vindobonensis Georgicus 2 as an example of a Georgian document represented in the Old Georgian language of the Khanmeti period ${ }^{49}$ Subsequent to Birdsall's and Shanidze's editions, a new edition of the evidence of Ms. Vindobonensis Georgicus 2 for the Protoevangelium of James appeared in 2007. Based on revisiting the evidence of the manuscript

46 J.N. Birdsall, "A Second Georgian Recension of the Protevangelium Jacobi," Le Muséon, 83 (1970), pp. 49-72.

47 J.N. Birdsall, “A Georgian Palimpsest in Vienna," Oriens Christianus, 53 (1969), pp. 108-112, here pp. 109-110 and 111.

48 G. Peradze, "Über die georgischen Handschriften in Österreich," Wiener Zeitschrift für die Kunde des Morgenlandes, 47-3-4 (1940), pp. 219-232, here pp. 220-224, on Ms. Vindobonensis georgicus 2 .

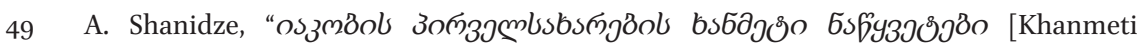

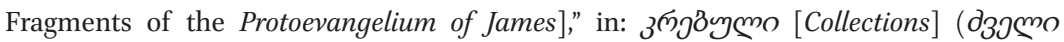

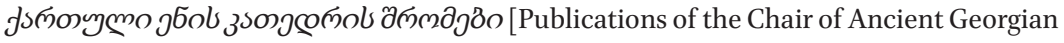
Studies], 20), Tbilisi, 1977, pp. 7-35 (from Ms. Vindob. Austrian National Library Georgian 2). 
with highly improved technical equipment, including infrared cameras, Jost Gippert was able to publish photos of the manuscript pages, improved readings that are revealed in his revised transcriptions of the text, and a critical edition of this palimpsest manuscript material from Vienna. Gippert's is indeed an impressive edition. ${ }^{50}$

\section{Status quaestionis: Some Work that Remains to Be Done}

Scholarship that has examined the text of the Georgian Protoevangelium of James in Ms. Sinai Georgian 6 and Ms. Vienna Georgicus 2 has concluded that both manuscripts witness to the same recension. Preliminary study suggests that additional manuscript evidence for the Georgian Protoevangelium of James on Mount Sinai constitutes a separate recension. Clearly, several tasks lie ahead then. One is to edit more fully the heretofore identified manuscript evidence for the different versions and recensions. Further tasks are to understand in detail the precise relationships between the Georgian version on the one hand and the Greek and the Syriac version on the other, and to examine Ms. Vienna Georgicus 2 in order to determine whether this material might offer new information concerning the relationship between the Georgian Protoevangelium and the Armenian Protoevangelium as well as the latter's reception in the Armenian Infancy Gospel. Thereafter, the results of such studies ought to be brought into conversation with the evidence for the existence of an Armenian Protoevangelium of James predating the late ninth century.

Due to the impact of the Protoevangelium on artistic expressions, any consideration of the status quaestionis of the transmission and reception of the Protoevangelium of James in the Caucasus requires a careful study of the art historical and ethno-musicological evidence that has been preserved. Some valuable examination of relevant illuminations in Armenian and Syriac manuscripts have been conducted by Thomas Mathews, Avedis Sanjian, and Nira Stone, among others. ${ }^{51}$ For the comparable material in the Georgian realm I

$5^{0}$ J. Gippert, Palimpsest Codex Vindobonensis georgicus 2 (Monumenta Palaeographica Medii Aevi: Series Ibero et Caucasia), Turnhout, 2007. For a review of this publication, see S.H. Rapp, in Speculum, 86.1 (2011), pp. 196-198.

Th.F. Mathews, "The Annunciation at the Well. A Metaphor of Armenian Monophysitism," in: Medieval Armenian Culture, eds. Th. Samuelian and M.E. Stone (University of Pennsylvania Armenian Text and Studies, 6), Chico, California, 1984, pp. 343-356; Th.F. Mathews and A.K. Sanjian, Armenian Gospel Iconography: the Tradition of the Glajor Gospel (Dumbarton Oaks Studies, 29), Washington, DC, 1991; Th.F. Mathews and A. Taylor, The Armenian Gospels of Gladzor. The Life of Christ Illuminated, Los Angeles, 2001, pp. 41-42 
am not aware of any studies. For the hymnographical, and thus ethno-musicological, traditions in both the Armenian and the Georgian realm, there are to my knowledge no examinations of the range of motifs that have their origins in the apocryphal realm more generally, and, with relevance for our topic, the Protoevangelium of James more specifically. My initial probes into these materials have convinced me that further efforts are promising.

Earlier on, I briefly referred to the question of the evidence of Georgian manuscripts for the liturgical usage of the Protoevangelium of James, with or without attestations of the actual text of the Protoevangelium of James in the manuscripts. This complex question can only be addressed satisfactorily when more of the manuscript evidence for the Georgian Protoevangelium of James has been edited. Here it is to be noted that van Esbroeck pointed out that the evidence of Georgian manuscripts to the text of the Protoevangelium of James is not limited to the two examples of which scholarship has taken note in its more elaborate efforts towards establishing critical editions of texts. In his doctoral work on the Georgian mravalt'avi collections, Van Esbroeck has called attention to the existence of a second recension of the Protoevangelium of James in Georgian, preserved in a liturgical manuscript on Mount Athos which appears to feature a text that is in greater harmony with the evidence of the canonical gospels. ${ }^{52}$ Robert Blake had signaled the existence of the manuscript witness for the text already early on in the 30 . $^{53}$ The edition of this evidence is to be included ideally in a digital edition of the Oriental versions of the Protoevangelium of James. In addition, the relationship of this version with the translation activities of Euthymius Mt'ac'mindeli requires study. My current explorations are bringing to the fore several further manuscript witnesses to the Georgian Protoevangelium of James that are associated with the Feast of Mary's Birth or other liturgical feast days, including Christmas. Yet the detailed presentation of the manuscript evidence, which comes from later centuries, and a discussion of its implications for the intersection of liturgical celebrations and the usage of apocryphal texts will have to remain as a topic for future studies.

and pl. 43; N. Stone, "Apocryphal Stories in Armenian Manuscripts," in: Apocryphes arméniens. Transmission-traduction-création-iconographie. Actes du colloque international sur la littérature apocryphe en langue arménienne (Genève, 18-20 septembre 1997), eds. V. Calzolari Bouvier, J.-D. Kaestli, and B. Outtier (Publications de l'Institut Romand des Sciences Bibliques, 1), Lausanne, 1999, pp. 161-169 and plates I-IX, here pp.163-165 and plates II-IV.

53 R.R. Blake, "Catalogue des manuscrits géorgiens de la bibliothèque de la Laure d'Iviron au Mont Athos," Revue de l'Orient Chrétien, 28 (1931-1932), pp. 289-361, here p. 315. 